\title{
THE PLEISTOCENE GLYPTODONTIDAE GRAY, 1869 (XENARTHRA: CINGULATA) OF COLOMBIA AND SOME CONSIDERATIONS ABOUT THE SOUTH AMERICAN GLYPTODONTINAE
}

\author{
ALFREDO E. ZURITA, ÁNGEL R. MIÑO-BOILINI \\ Centro de Ecología Aplicada del Litoral, CONICET, Ruta 5, km 2,5, 3400, CC 128, Corrientes, Argentina. \\ azurita@cecoal.com.ar,angelmioboilini@yahoo.com.ar
}

\author{
ANALÍA FRANCIA \\ División Paleontología de Vertebrados, Facultad de Ciencias Naturales y Museo, Paseo del Bosque s/n, B1900FWA, \\ La Plata, Argentina. analiafrancia@yahoo.com.ar
}

JOSÉ E. ARENAS-MOSQUERA

Museo Geológico Nacional José Royo y Gómez, Servicio Geológico Colombiano, Colombia.jarenas@ingeominas.gov.co

\begin{abstract}
Until recently, one well-characterized Pleistocene genus of the subfamily Glyptodontinae (Glyptodon ca. 1.08-0.0011 My) was recognized in South America. In recent times, some authors have demonstrated, through the re-analysis of material originally classified as Glyptodon Owen and Hoplophorus Lund, the presence of a second species belonging to the North American glyptodontine Glyptotherium Osborn (ca. 58-12 ky BP), currently known from in Venezuela and Brazil. This situation implies the need for a new study, with modern taxonomical criteria, of those materials belonging to the Glyptodontinae, particularly in those territories where the knowledge of these taxa is scarce. Presented here is a new analysis of the Pleistocene Glyptodontidae from Colombia, including some taxonomic and paleobiogeographic remarks. The results show that the only reported Glyptodontidae specimens in Colombia belong to Glyptodon sp. In turn, the evidence suggests that only one single species of Glyptotherium is present in South America, currently assigned to Glyptotherium cf. Gl. cylindricum. However, a more accurate analysis is necessary to confirm or refute this taxonomic identification. To date, Glyptotherium present has been found only in an area parallel to the Caribbean Sea and the Atlantic Ocean (northern Venezuela and eastern Brazil), up to $20^{\circ} \mathrm{S}$, and is always linked to lowlands. This geographic distribution agrees with the proposition of an eastern corridor during the Great American Biotic Interchange. Below this latitude, the only recorded glyptodontine corresponds to Glyptodon, which is also recorded in a strip parallel to the Cordillera de Los Andes reaching Colombia and Venezuela. Taking into account this distribution, the presence of this genus in Central America cannot be discarded.
\end{abstract}

Key words: taxonomy, South America, Pleistocene, Glyptodontinae, osteoderms.

RESUMO - Até pouco tempo, um único gênero endêmico do Pleistoceno pertencente à subfamília Glyptodontinae (Glyptodon ca. 1.08$0.0011 \mathrm{Ma}$ ) era reconhecido para a América do Sul. Recentemente, alguns autores têm demonstrado, através de novas análises do material originalmente classificado como Glyptodon Owen e Hoplophorus Lund, a presença de uma segunda espécie de Glyptodontinae pertencente ao gênero norte-americano Glyptotherium ( $c$. 58-12 ka AP), atualmente presente na Venezuela e Brasil. Essa situação implica na necessidade de uma nova análise do material referente à Glyptodontinae, com um critério taxonômico mais moderno, especialmente em localidades onde o conhecimento desse grupo é escasso. Na presente contribuição, é apresentada uma nova análise taxonômica dos Glyptodontidae encontrados na Colômbia, incluindo algumas observações taxonômicas e paleobiogeográficas. Os resultados demonstram que o único relato de Glyptodontidae para a Colômbia pertence à Glyptodon sp. Porém, a evidência sugere que somente uma única espécie de Glyptotherium Osborn está presente na América do Sul, atualmente atribuída a Glyptotherium cf. Gl. cylindricum. Uma análise mais precisa é necessária para confirmar sua identificação taxonômica. Até agora, Glyptotherium está presente em uma faixa paralela ao Mar Caribenho e Oceano Atlântico (Norte da Venezuela e região oriental do Brasil), até $20^{\circ} \mathrm{S}$, e sempre vinculado à terras baixas. Essa distribuição geográfica concorda com a proposição de um corredor oriental durante o Grande Intercâmbio Biótico Americano. Abaixo dessa latitude, o único registro de Glyptodontinae corresponde a Glyptodon, o qual também é registrado em uma faixa paralela a Cordilheira dos Andes, alcançando Colômbia e Venezuela. Levando em consideração essa distribuição, a presença desse gênero na América Central não deveria ser descartada.

Palavras-chave: taxonomia, América do Sul, Pleistoceno, Glyptodontinae, osteodermos.

\section{INTRODUCTION}

Knowledge of the geographic distribution of the Pleistocene family Glyptodontidae Gray, 1869 (Cingulata) in South America has recently been discussed and improved (see Carlini et al., 2008; Zurita et al., 2009, 2011 a; Oliveira et al., 2009, 2010). To date, the evidence suggests that the main lineages of the Glyptodontidae show a particular paleogeographic pattern, because most of their records are restricted to southern areas of South America (Zurita et al., 2009). In fact, the largest diversity of Pleistocene Glyptodontidae is present in the current territory of the 
Pampean region (Argentina) and adjacent areas, such as the Mesopotamian region and central-northern areas of Argentina, the western sector of Uruguay and southern Brazil; latitudinally, this area is located between $39^{\circ} \mathrm{S}$ and $20^{\circ} \mathrm{S}$. This is especially evident in some taxa, such as the Doedicurinae (Doedicurus Burmeister, 1874 and Plaxhaplous Ameghino, 1884), "Hoplophorinae" Hoplophorini (Neosclerocalyptus Paula Couto, 1957), and Neuryurini (Neuryurus Ameghino, 1889) (see Carlini \& Scillato-Yané, 1999; Rinderknecht, 1999; Pomi, 2008; Zurita et al., 2011c; Soibelzon, 2008; Soibelzon et al., 2010; Ubilla et al., 2004; Ribeiro \& Scherer, 2009).

From a paleogeographic point of view, only three taxa are certainly recorded above $20^{\circ} \mathrm{S}$ (see Zurita et al., 2009). One particular intertropical Glyptodontidae, Hoplophorus Lund, 1839 seems to be restricted to about $20^{\circ} \mathrm{S}$ in the current territories of Brazil and Bolivia (see Hoffstetter, 1963; Paula-Couto, 1957; Porpino et al., 2010); Paula Couto (1983) reported Hoplophorus from the Acre region, Brazil, but the material (only one isolated osteoderm) has never been figured. Other taxa, the genus Panochthus Burmeister, 1866, had a wider geographic distribution, reaching probably from $49^{\circ} \mathrm{S}$ (Tauber \& Palacios, 2007) to $5^{\circ} \mathrm{S}$ (Moreira, 1965; Porpino \& Bergqvist, 2002; Porpino et al., 2004; Zamorano et al., 2012). The evidence suggests that Panochthus is a taxon with wide ecological tolerance, since its records come from arid/semiarid/cold (Carlini \& Scillato-Yané, 1999) and wetter and warmer environments (Carlini et al., 2008).

Besides this, the most recorded taxa in South America are the Glyptodontidae Glyptodontinae, since their latitudinal distribution ranges from southern Buenos Aires Province (Argentina) to Colombia and Venezuela (Carlini et al., 2008; Rincón et al., 2008) (Figure 1). Until recently, one well characterized genus, Glyptodon Owen, 1839, was recorded in South America. This situation changed after Carlini et al. (2008) and Oliveira et al. (2010) reinterpreted some latest Pleistocene specimens from Venezuela and Brazil, originally classified as Glyptodon and Hoplophorus, as belonging to the North American glyptodontine Glyptotherium Osborn, 1903 (see Gillette \& Ray, 1981). As suggested by Carlini et al. (2008) and Carlini \& Zurita (2010), this can be interpreted as the result of a bidirectional migratory pattern during the GABI.

This situation implies the need for a new revision of those materials belonging to Pleistocene Glyptodontinae in South America in order to clarify their taxonomy, especially in those territories where this group is poorly known. In particular, in South America, Colombia is one of the least known places regarding the presence of Pleistocene Glyptodontidae. The improvement in knowledge on the paleogeographic distribution of both taxa, Glyptodon and Glyptotherium, will allow us to hypothesize some considerations about the likely dispersal route of Glyptotherium in South America after its entry.

Therefore, this contribution aims to provide a taxonomic revision of the Glyptodontinae present in the Pleistocene of Colombia, and present some paleobiogeographic and taxonomic considerations about the genera Glyptodon and Glyptotherium.

Institutional abbreviations. AMNH, American Museum of Natural History, New York, USA; ICN, Instituto de Ciencias Naturales de la Universidad Nacional de Colombia, Bogotá, Colombia; IGM, Museo Geológico Nacional "José Royo y Gómez", INGEOMINAS, Bogotá, Colombia; MCA, Museo de Ciencias Naturales "Carlos Ameghino", Mercedes, Buenos Aires, Argentina; MCN, Museo de Ciencias, Caracas, Venezuela; MHNLS, Museo de Historia Natural de La Salle, Bogotá, Colombia; MALV, Museo Arqueológico Los Vados, Municipio de Los Patios, Departamento de Norte de Santander, Colombia; PVE-F, Colección Paleontología de Villa Escolar, Formosa, Argentina; UNEFM- CIAAP, Universidad Nacional Experimental Francisco Miranda, Coro, Centro de Investigaciones Antropológicas, Arqueológicas y Paleontológicas, Venezuela.

Other abbreviations. $\mathbf{n} / \mathbf{n}$, without official catalog number; GABI, Great American Biotic Interchange.

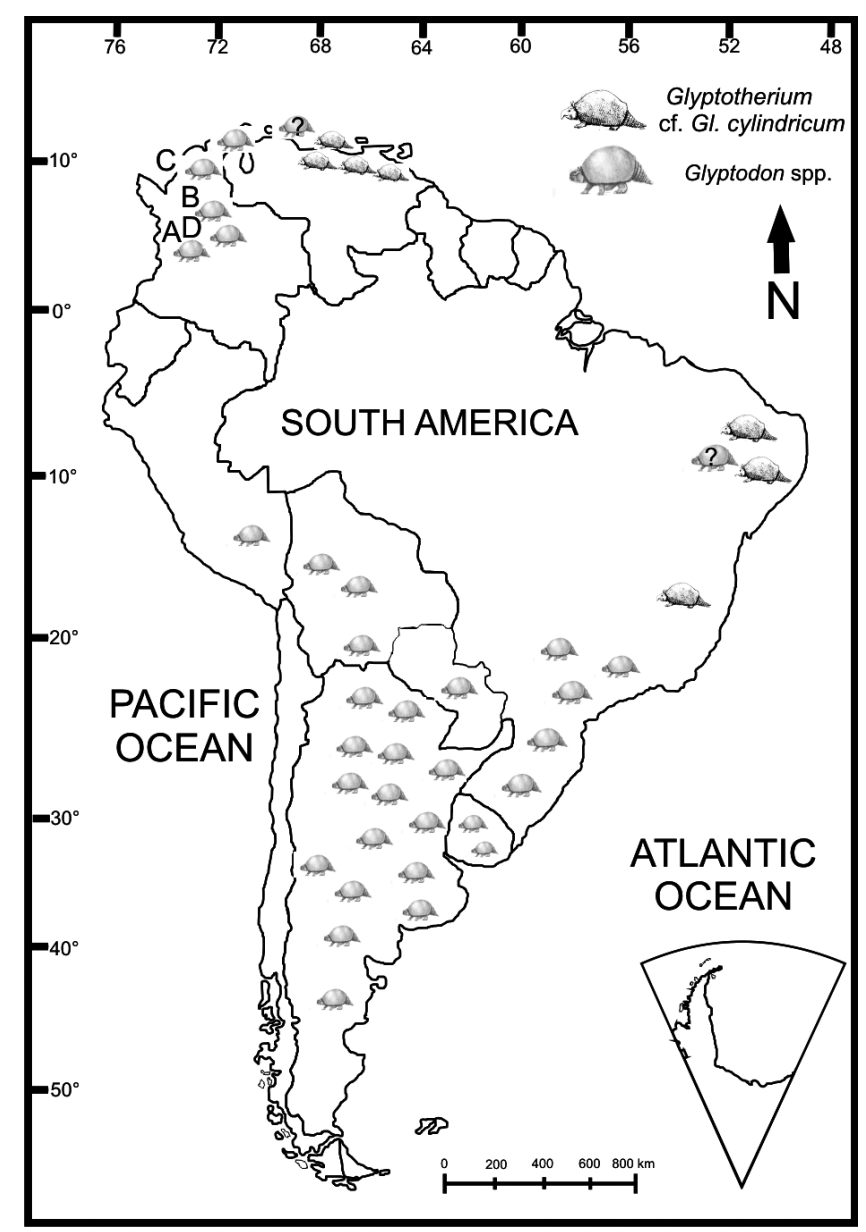

Figure 1. Geographic distribution of Glyptodon and Glyptotherium cf. Gl. cylindricum in South America. In Colombia: A, Pubenza, Tocaima, Cundinamarca; B, Los Patios, Norte de Santander, C, Santa Marta, Magdalena; D, Quebrada Las Lajas, Villavieja Village, Huila. 


\section{SYSTEMATIC PALEONTOLOGY}

\author{
Superorder XENARTHRA Cope, 1889 \\ Order CINGULATA Illiger, 1811 \\ Suborder GLYPTODONTIA Ameghino, 1885 \\ Family GLYPTODONTIDAE Gray, 1869 \\ Subfamily GLYPTODONTINAE Gray, 1869
}

Glyptodon Owen, 1839

Type species. Glyptodon clavipes Owen, 1839.

Glyptodon sp.

(Figure 2 A-I)

Referred material and geographic and stratigraphic provenance. MALV-229, 845: two osteoderms of the dorsal carapace, Los Patios, Norte de Santander (a. $7^{\circ} 51^{\prime} \mathrm{N}$, $72^{\circ} 29^{\prime} \mathrm{W}$ ), Colombia, Pleistocene. MHNLS 2348, 2349: two osteoderms of the dorsal carapace and one of the most lateral area, near the ventral margin (this material was referred by Bombin (1982) as Glyptodon clavipes Owen), El Rosario, Norte de Santander ( $\left.7^{\circ} 51^{\prime} \mathrm{N}, 72^{\circ} 29^{\prime} \mathrm{W}\right)$ and Sierra Nevada de Santa Marta (Magdalena), Colombia, Pleistocene. ICNPubA1 210-223, ICN-Pub07(01) 210-220, ICN-PubD $210-$ 220, ICN-Pub 84 153, ICN-Pub 84 163: some osteoderms of the dorsal carapace, and many small and irregular osteoderms, Pubenza, Tocaima, Cundinamarca (a. $4^{\circ} 24^{\prime}$ N, $74^{\circ} 44^{\prime} \mathrm{W}$ ), Colombia, latest Pleistocene (see Correal-Urrego et al., 2005). IGM p174998 (a,b,c), IGM p174999 (a,b.c), IGM p175000 $(a, b, c)$ : nine osteoderms of the dorsal carapace from sandstone levels into conglomerate of Mesa Formation, Quebrada Las Lajas, NW Villavieja Village, Huila $\left(3^{\circ} 14^{\prime} \mathrm{N}, 75^{\circ} 12^{\prime} \mathrm{W}\right)$, Colombia, Pleistocene (see Butler, 1942; Fields, 1959; Takay et al., 1992) (Figure 1).

Description and comparisons. As mentioned above, the reports of Glyptodontidae are very scarce in Colombia, and the only species reported is Glyptodon clavipes Owen, 1839. In fact, the published contributions are restricted only to those of Apolinar (1926), Bombin (1982) and Correal-Urrego et al. (2005), plus two new osteoderms from Los Patios (Norte de Santander) and nine from Quebrada Las Lajas, Villavieja town (Huila).

A new analysis of the available materials shows that the morphology of the exposed surface of the osteoderms is typical of Glyptodon and different from the known South American Glyptotherium specimens. The annular and radial sulci are somewhat wider than those observed in Glyptotherium, with almost vertical sides and a wide, almost flat bottom, forming an angle of $90^{\circ}$; in Glyptotherium, the sulci show a more concave morphology. In addition, in many osteoderms of Glyptotherium (see Oliveira et al., 2010; p. 357, fig. 3A-B; MCN n/n; UNFEMCIAAP $n / n$ ) it is possible to observe numerous foramina; the ducts that correspond to the foramina are arranged obliquely to the osteoderm surface. To date, this particular morphology has been observed only in the South America
Glyptotherium and in the North American species $G l$. floridanum (Simpson, 1929) (AMNH 23547); in contrast, in Glyptodon the surface is clearly rugose, but without this kind of foramina.

The evidence clearly shows that the osteoderms classified as G. clavipes by Bombin (1982) must be assigned only to Glyptodon sp. (Figures 2C-D). In addition, Bombin (1982: 1) did not mention any character to support this assignation. Interestingly, the osteoderms figured by Correal-Urrego et al. (2005) (Figures 2E-F) appear to be associated with an archaeological site dated to ca. $16 \mathrm{ky}$ BP. Together with these osteoderms, there are many small and irregular osteoderms that show a morphology very similar to that of those figured by Tauber \& Di Ronco (2000) and Soibelzon et al. (2006) belonging to the lateral areas of the skull and pubic region (Figure $2 \mathrm{G}$ ). The two osteoderms from Los Patios (Norte de Santander) did not show any significant differences from those of Glyptodon (Figures 2A-B). Finally, the nine osteoderms from Quebrada Las Lajas show the typical morphology observed in Glyptodon. The annular and radial sulci have almost vertical sides and a wide, almost flat bottom, forming an angle of $90^{\circ}$, and are somewhat wider than in Glyptotherium, which shows a more concave sulci morphology (Figures 2H-I).

To summarize, to date, all the records of the Glyptodontinae belong to Glyptodon, which represents the only Glyptodontidae recorded in the Pleistocene of the current territory of Colombia.

\section{DISCUSSION}

\section{Glyptotherium and Glyptodon in South America}

Several species of Glyptodon (ca. 13) have been recognized, most of them without a truly diagnostic morphological characterization (Ameghino, 1889; Mones, 1986; Soibelzon et al., 2006). However, some preliminary revisions have suggested there could be no more than five valid species: G. munizi Ameghino, 1881 (Ensenadan Age/ Stage; early Pleistocene-middle Pleistocene; see Soibelzon et al., 2006; Zurita et al., 2009), G. elongatus Burmeister, 1866, G. reticulatus Owen, 1845 (Bonaerian-Lujanian Ages; middle Pleistocene-early Holocene; see Ameghino, 1889; Duarte, 1997), G. clavipes Owen, 1839, and a probable morphotype with a complex nomenclatural situation (see Zurita et al., 2009, 2011b). Interestingly, this latter species is probably restricted to Andean areas, having a smaller size than the Pampean species (e.g. G. elongatus, G. munizi). This particular situation could be due to the fact that such mountain habitats support smaller species (see Rodriguez et al., 2008). This is also concordant with a similar condition observed in Peruvian Megatheriinae sloth (see Pujos, 2008).

The evidence shows that at least one of the most cited species of Glyptodon is not valid because the main characters of G. perforatus Ameghino, 1889 are not diagnostic (e.g. PVE-F 85, MCA 2013) (see Zurita et al., 2011b).

The situation for Glyptotherium is somewhat different, with in having undergone a recent taxonomic revision (see 
A
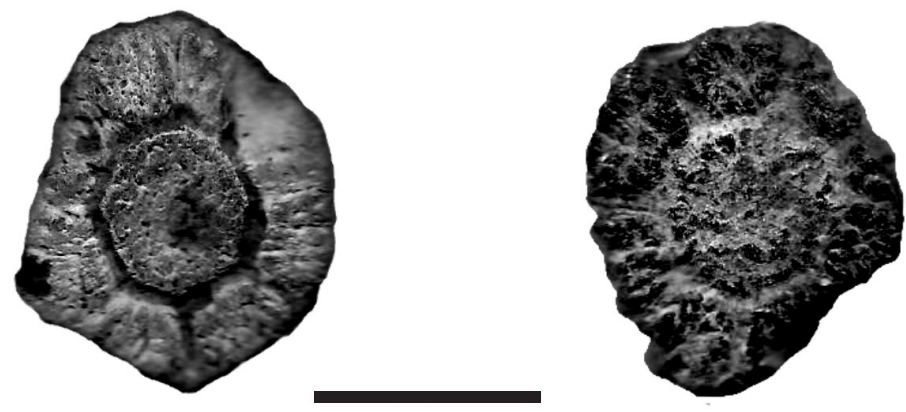

B

C
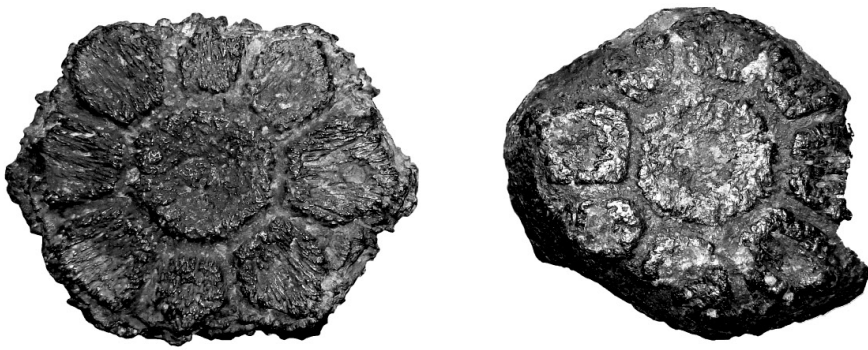

D

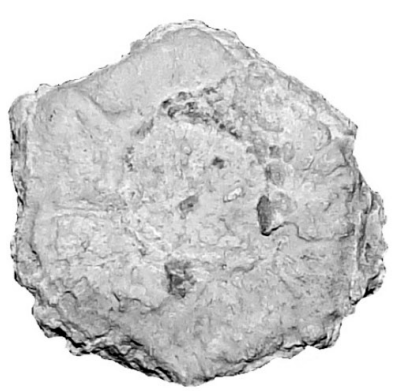

E

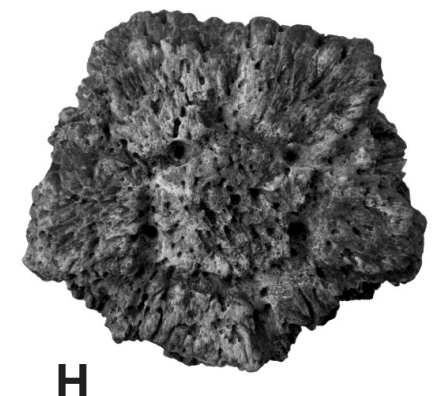

$\mathbf{F}$

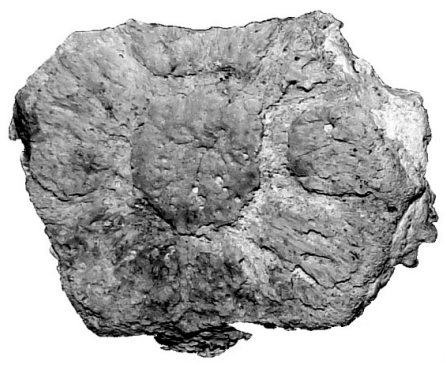

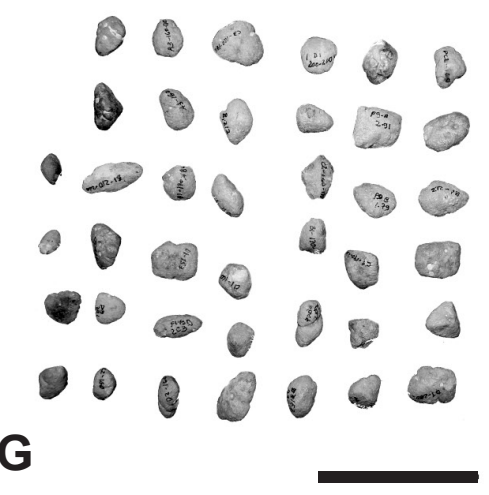
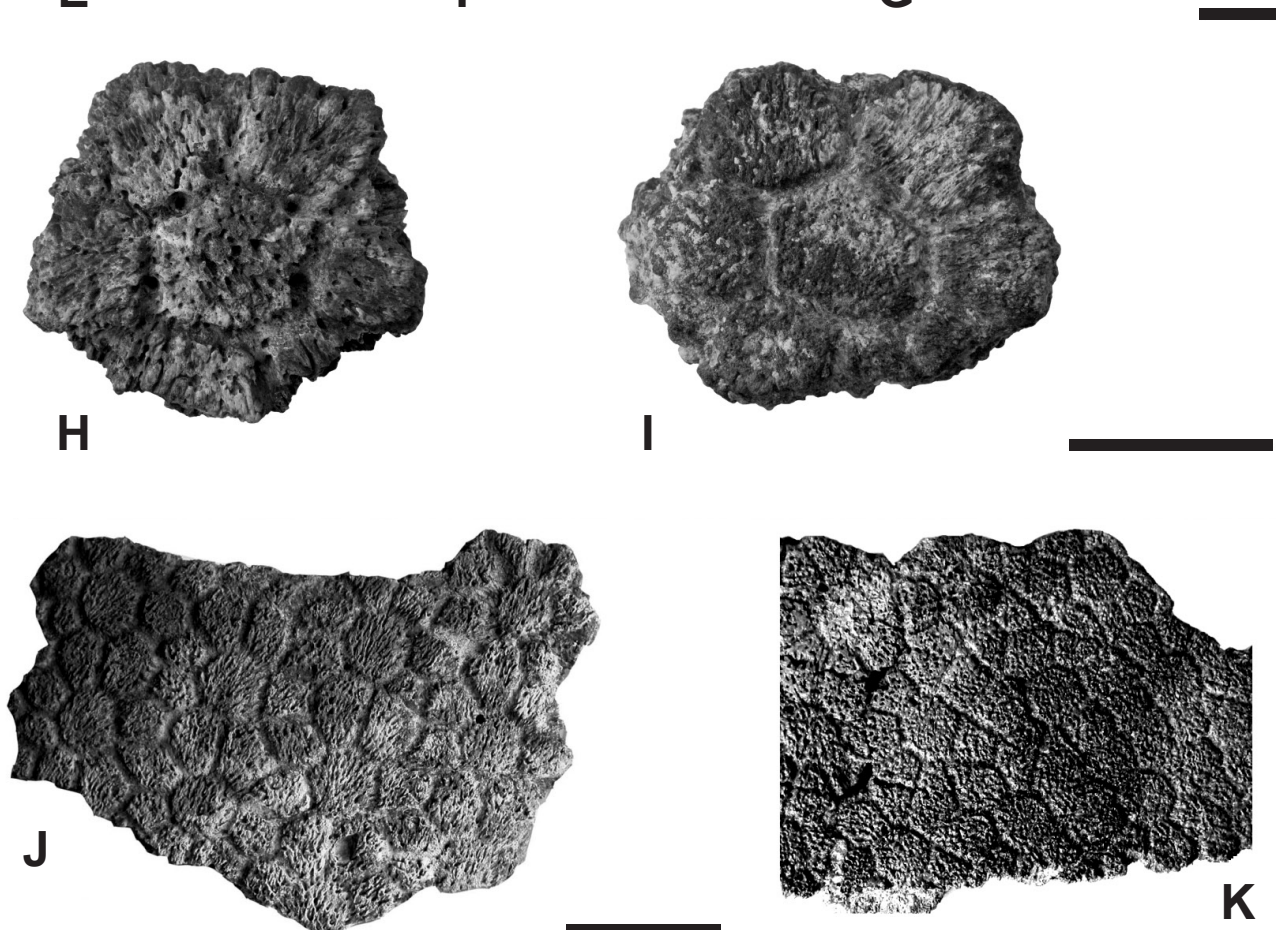

Figure 2. Glyptodon sp. Osteoderms of the dorsal carapace in dorsal view. A-B, MALV 229, 845, Los Patios Village, Norte de Santander; C-D, MHNLS 2348-2349, El Rosario Village, Norte de Santander and unknown locality Santa Marta, Magdalena; E-G, ICN (n/n) PubA1 210-223, Pub07 (01) 210-220, PubD 210-220, Pub 84 153, Pub 84 163, Pubenza, Tocaima Village, Cundinamarca; G, osteoderms of the facial region?; H-I, IGM p174998, 174999, Quebrada Las Lajas, Villavieja Village, Huila. Glyptotherium cf. Gl. cylindricum. Osteoderms of the dorsal carapace in dorsal view; J-K, MCN (n/n), Falcon State, Venezuela. Scale bars $=30 \mathrm{~mm}$. 
Gillette \& Ray, 1981). According to Gillette \& Ray (1981), five species can be recognized; however, it is possible that some of them could be synonymous [e.g. Gl. texanum Osborn, 1903 and Gl. arizonae (Gidley, 1926) (Carranza-Castañeda \& Gillette, 2011)]. The late Pleistocene species are $G l$. cylindricum (Brown, 1912) Gl. mexicanum (Cuatáparo \& Ramirez, 1875) and Gl. floridanum. As observed previously (Zurita et al., 2008) both, Glyptodon and Glyptotherium, are well differentiated by many characters, especially at the level of the dorsal carapace and skull.

At least for the South American specimens of Glyptotherium, it is possible to differentiate them from Glyptodon on the basis of the osteoderms of the dorsal carapace (see Carlini et al., 2008; Oliveira et al., 2009; 2010). Among the most prominent characters, the osteoderms of Glyptotherium show a less evident development of the annular and radial sulci and, in some cases, it is possible to observe very developed small foramina on all of the dorsal surface (e.g. MCC 2202, 268-V). As mentioned by Dantas et al. (in press), other usually mentioned characters, such as the number of peripheral figures, are common to both genera. In this context, a comparison with the material figured by Oliveira et al. (2010) did not show any significant differences from the Venezuelan material, suggesting that one single species is present in South America.

Outside southern South America, northern records of Glyptodon are usually attributed to G. clavipes (Bombin, 1982; Bocquentin-Villanueva, 1982; Paula-Couto, 1983; Pujos \& Salas, 2004; Dantas et al., 2005; Dantas, 2009; Rincón \& White, 2007; Rincón et al., 2008), whereas southern records are sometimes reported as G. reticulatus (Kerber et al., 2010). In this sense, it is important to mention that most of these assignations were carried out on the basis of fragments of the dorsal carapace and/or isolated osteoderms, which did not allow an accurate taxonomic identification to be obtained. This is mainly due to the noticeable morphological variations that the osteoderms have depending on their location on the dorsal carapace, which for most species have not been quantified enough (but see Duarte, 1997).

In this context, the new analysis of the known materials from Colombia shows that they belong to Glyptodon sp. The absence of Glyptotherium in this territory and in southern areas could be related to the presence of mountain barriers (see de Porta, 2003; Mora et al., 2008). In fact, the distribution of the records of Glyptotherium allows us to suggest that, after its entry into South America during the GABI, Glyptotherium could have followed a migratory route parallel to the Caribbean Sea (see Carlini et al., 2008) and the Atlantic Ocean towards southern areas, reaching up to $20^{\circ} \mathrm{S}$ (Oliveira et al., 2010) (Figure 1).

In this scenario, Oliveira et al. (2010) proposed a paleobiogeographic distribution pattern for Glyptotherium and Glyptodon, in which Glyptotherium occupied northeastern and southeastern areas of Brazil whereas Glyptodon occupied the current territories of Argentina, Bolivia, Uruguay, Paraguay and the southernmost areas of Brazil (Figure 1). Recently, Rincón \& White (2007), Rincón et al. (2008) and Dantas et al. (in press) have reported the occurrence of Glyptodon in Venezuela and in the intertropical region of Brazil. The taxonomic identification carried out by Dantas et al. (in press) seems to be very doubtful, mainly because of the poor preservation of the osteoderms. In addition, the main character mentioned (a concavity in each central figure of the osteoderms) is also present in some other glyptodontines such as Glyptotherium arizonae (AMNH 21808). In contrast, the taxonomic identification carried out by Rincón \& White (2007) and Rincón et al. (2008) seems to be more accurate, because the material shows a clear affinity with Glyptodon. Despite this, if this is correct, Glyptotherium and Glyptodon could have shared the same geographic distribution in central-north and eastern areas of South America (Venezuela and Brazil, respectively), approximately from $11^{\circ} \mathrm{N}$ to $10^{\circ} \mathrm{S}$ (Figure 1). In this context, it is important to remark that this sympatry does not imply necessarily that both genera coexisted.

However, some noteworthy considerations can be made. Interestingly, Glyptodon is the only glyptodontine present in the southernmost region of South America, up to $20^{\circ} \mathrm{S}$. Above $20^{\circ} \mathrm{S}$, in the western part of South America, parallel to the Cordillera de Los Andes, Glyptodon is the only observed glyptodontine (and the most frequently recorded Glyptodontidae), its recorded presence reaching over 3300 m (Pujos \& Salas, 2004), up to Colombia and Venezuela. In turn, Glyptotherium is recorded only in an area parallel to the Caribbean Sea and the Atlantic Ocean, and always associated with lowlands (Figure 1). The geographic distribution of Glyptotherium agrees with the eastern corridor proposed by Webb (1978, 1985; see also McDonald, 2005), which was used by many clades of mammals as a dispersal route. In contrast to Glyptodon, the evidence shows that Glyptotherium is recorded in the lowlands.

To date, Glyptodon is recorded only in South America, but taking into account the records published by Rincón et al. (2008), the presence of Glyptodon in Central America cannot be discarded. Therefore, a modern taxonomic revision of Central America Glyptodontinae is required.

Like Glyptodon, Glyptotherium seems to have been present in arid/semiarid areas (e.g. Taima Taima, Venezuela; see Ochsenius, 1978, 1980) and in the intertropical region of South America (e.g. Minas Gerais, Brazil). A recent analysis based on stable isotopes performed by Pérez-Crespo et al. (2012) has shown that the late Pleistocene Mexican species of Glyptotherium were able to consume both $\mathrm{C} 4$ and $\mathrm{C} 3$ plants, suggesting that this taxon was a grazer adapted to open environments, like Glyptodon (Pérez et al., 2000; see also Vizcaíno et al., 2011).

\section{CONCLUSIONS}

In the current territory of Colombia, the evidence shows that, to date, the remains of Glyptodontidae must be referred to Glyptodon sp. In South America, only one Glyptotherium species can be recognized. This species shares some characters with the North American species Gl. cylindricum. However, 
a more accurate analysis is necessary to either confirm or refute this hypothesis. To date, Glypotherium has only been recorded in South America in a strip parallel to the Caribbean Sea and to the Atlantic Ocean, up to $20^{\circ} \mathrm{S}$. This geographic distribution agrees with the eastern corridor proposed by Webb (1985) during the GABI. The records of Glyptotherium from Venezuela ( $c a .14-12$ ky BP) and eastern Brazil (ca. 58-68 ky BP) are associated with lowlands. In turn, Glyptodon is the only Glyptodontinae present in an area parallel to the Cordillera de Los Andes, reaching up to $3300 \mathrm{~m}$. Both Glyptodon and Glyptotherium are possibly recorded in sympatry from $11^{\circ} \mathrm{N}$ to $10^{\circ} \mathrm{S}$. This does not necessarily imply that the two genera coexisted. Both genera can be recognized on the basis of isolated osteoderms of the dorsal carapace of adult specimens; in contrast, the osteoderms of juvenile individuals show the same morphology. Taking the northern records of Glyptodon in South America into account, the presence of this genus in Central America cannot be discarded.

\section{ACNOWLEDGMENTS}

The authors thank the staff at the Museo Arqueológico Los Vados, Museo de Historia Natural de La Salle (Bogotá), Instituto de Ciencias Naturales de la Universidad Nacional de Colombia and Museo Geológico Nacional "José Royo y Gómez", Servicio Geológico Colombiano (formerly Ingeominas) for allowing the study of the materials presented here. A. Mones and an anonymous reviewer are also thanked for their thorough reviews and helpful suggestions. This work was funded by project grants PICTO-UNNE (2007-00164), PICT 1285/2008, and PI Q002-11.

\section{REFERENCES}

Ameghino, F. 1881. La antigüedad del hombre en el Plata. París, G. Masson, Buenos Aires, Igon Hermanos, Tomo 2, 557 p.

Ameghino, F. 1884. Excursiones geológicas y paleontológicas en la Provincia de Buenos Aires. Boletín de la Academia Nacional de Ciencias de Córdoba, 6:161-257.

Ameghino, F. 1885. Nuevos restos de mamíferos fósiles oligocenos recogidos por el Profesor Pedro Scalabrini y pertenecientes al Museo Provincial de la Ciudad del Paraná. Boletín de la Academia Nacional de Ciencias en Córdoba, 8:5-207.

Ameghino, F. 1889. Contribución al conocimiento de los mamíferos fósiles de la República Argentina. Actas de la Academia Nacional de Ciencias de Córdoba, 6:1-1027+ Atlas.

Apolinar, Hno. M. 1926. Smilodon y Glyptodon en Colombia. Boletín de la Sociedad Colombiana de Ciencias Naturales, 15:112.

Bocquentin-Villanueva, J. 1982. Notas sobre la fauna del Pleistoceno superior de Taima-Taima depositada en el Museo del Hombre de Coro, Estado Falcón, Venezuela. Acta Cientifica Venezolana, 33:479-487.

Bombin, M. 1982. Ocurrencia de Glyptodon clavipes en Colombia. Revista CIAF, Bogotá, 6:17-18.

Brown, B. 1912. Brachyostracon, a new genus of glyptodonts from México. American Museum of Natural History Bulletin, 31:167-177.

Burmeister, H. 1866. Einige Bemerkungen über die im Museum zu Buenos Aires befindlichen Glyptodonarten. Zeitschrift für die Gesammten Naturwissenschaften, 28:138-142.
Burmeister, H. 1870-1874. Monografía de los glyptodontes en el Museo Público de Buenos Aires. Anales del Museo Público de Buenos Aires, 2:367-377.

Butler, J.W. 1942. Geology of Honda District, Colombia. Bulletin of the American Association of Petroleum Geologists, 26:793-837.

Carlini, A.A. \& Scillato-Yané, G.J. 1999. Evolution of Quaternary xenarthrans (Mammalia) of Argentina. Quaternary of South America and Antarctic Peninsula, 12:149-175.

Carlini, A.A.; Zurita, A.E. \& Aguilera, O. 2008. North American glyptodontines (Xenarthra, Mammalia) in the Upper Pleistocene of Northern South America. Paläontologische Zeitschrift, 82:139-152. doi:10.1007/BF02988404

Carlini, A.A. \& Zurita, A.E. 2010. An introduction to Cingulate evolution and their evolutionary history during the Great American Biotic Interchange: biogeographical clues from Venezuela. In: M.R. Sánchez-Villagra; O. Aguilera \& A.A. Carlini (eds.) Urumaco \& Venezuelan Palaeontology, Indiana University Press, p. 233-255.

Carranza-Castañeda, O. \& Gillette, D.D. 2011. Origin of North American glyptodonts: Glyptotherium texanum from Mexico and the United States (Pliocene Epoch). In: CONGRESO LATINOAMERICANO DE PALEONTOLOGÍA DE VERTEBRADOS, 4, 2011. Resúmenes, San Juan, p. 122.

Cope, E. D. 1889. The Edentata of North America. The American Naturalist, 23:657-664.

Correal-Urrego, G.; Gutiérrez-Ulano, J.; Calderón, K.J. \& VilladaCardozo, D.C. 2005. Evidencias arqueológicas y megafauna extinta en un salado del tardiglacial superior. Boletín de Arqueología, 20:1-58.

Cuatáparo, J.N. \& Ramírez, S. 1875. Descripción de un mamífero fósil de especie desconocida perteneciente al género "Glyptodon." Boletín de la Sociedad Mexicana de Geografia y Estadística (México), 3:354-362.

Dantas, M.T. 2009. Primeiro registro de fósseis de mamíferos pleistocênicos em caverna de Sergipe, Brasil. Revista Brasileira de Paleontologia, 12:161-164. doi:10.4072/rbp.2009.2.06

Dantas, M.T.; Zucon, M.H. \& Ribeiro, A.M. 2005. Megafauna pleistocênica da Fazenda Elefante, Gararu, Sergipe, Brasil. Geociências, 24:277-287.

Dantas, M.T.; Melo França, L; Cozzuol, M.A. \& Rincón, A.D. in press. About the occurrence of Glyptodon sp. in the Brazilian Intertropical Region. Quaternary International. doi:10.1016/j. quaint.2011.06.024

de Porta, J. 2003. La formación del istmo de Panamá. Su incidencia en Colombia. Revista de la Academia Colombiana de Ciencias, 27:191-216.

Duarte, R.G. 1997. Gliptodontes del Pleistoceno tardío de Aguas de las Palomas, Campo de Pucará, Catamarca, Argentina. Variaciones morfológicas del caparazón de Glyptodon reticulatus Owen, 1845. Ameghiniana, 34:345-355.

Fields, R.W. 1959. Geology of the La Venta Badlands Colombia, South America. University of California Publications in Geological Sciences, 32:405-444.

Gidley, J.W. 1926. Fossil Proboscidea and Edentata of the San Pedro Valley, Arizona. United States Geological Survey Professional Paper, 140B:83-95.

Gillette, D.D. \& Ray, C.E. 1981. Glyptodonts of North America. Smithsonian Contributions to Paleobiology, 40:1-251.

Gray, J.E. 1869. Catalogue of carnivorous, pachydermatous, and edentate Mammalia in the British Museum. London, British Museum, 398 p.

Hoffsetter, R. 1963. La faune Pléistocène de Tarija (Bolivie). Nota préliminaire. Bulletin du Muséum d'Histoire Naturelle, 35:194-203. 
Illiger, C. 1811. Prodromus systematis mammalium et avium additis terminis zoographicis utriudque classis. Berolini, C. Salfeld, $301 \mathrm{p}$.

Kerber, L.; Kinoshita, A.; José, F.A.; Figuereido, A.M.G.; Oliveira, E.V. \& Baffa, O. 2010. Electron Spin Resonance dating of the southern Brazilian Pleistocene mammals from Touro Passo Formation, and remarks on the geochronology, fauna and palaeoenvironments. Quaternary International, 245:201-208. doi:10.1016/j.quaint.2010.10.010

Lund, P.W. 1839. Blik paa Brasiliens dyreverden för sidste jordomvaeltning. Anden afhandling: Pattedyrene (Lagoa Santa d. 16de novbr. 1837). Det kongelige Danske Videnskabernes Selskabs naturvidenskabelige og mathematiske Afhandlinger, 8:61144 (p. 184, of separatum), pls. $113+(1)$.

McDonald, G.H. 2005. Paleoecology of extinct Xenarthrans and the Great American Biotic Interchange. Bulletin of the Florida Museum of Natural History, 45:319-340.

Mones, A. 1986. Palaeovertebrata Sudamericana. Catálogo sistemático de los vertebrados fósiles de América del Sur. Parte I. Lista preliminar y bibliografía. Courier Forschungsinstitut Senckenberg, 82:1-625.

Mora, A.; Parra, M.; Strecker, M.R.; Sobel, E.R.; Hooghiemstra, H.; Torres, V. \& Vallejo-Jaramillo, J. 2008. Climatic forcing of asymmetric orogenic evolution in the Eastern Cordillera of Colombia. Geological Society of America Bulletin, 120:930-949. doi:10.1130/B26186.1

Moreira, E.L. 1965. Notas prévias sobre nova espécie do mamífero fóssil do Estado do Ceará, Brasil. Hy Hy Té, Revista da Faculdade de Filosofia do Crato, 2:41-44.

Ochsenius, C. 1978. The Peri-Caribbean arid belt context during the Late Pleistocene. In: C. Ochsenius \& R. Gruhn (eds.) TaimaTaima: a Late Pleistocene Paleoindian Kill Site it, Northernmost South America, p. 35-40. (South American Quaternary Documentation Program).

Ochsenius, C. 1980. Cuaternario en Venezuela. Introducción a la paleoecolgía en el norte de Suramérica. Cuadernos Falconianos, 3:1-37.

Oliveira, E.V.; Barreto, A.M.F. \& Alves, R.S. 2009. Aspectos sistemáticos, paleobiogeográficos e paleoclimáticos dos mamíferos fósseis do Quaternário de Fazenda Nova, Pernambuco, nordeste do Brasil. Gaea, 5:75-85. doi:10.4013/gaea.2009.52.04

Oliveira, E.V.; Porpino, K. \& Barreto, A.L.M.F. 2010. On the presence of Glyptotherium in the Late Pleistocene of Northearthern Brazil, and the status of "Glyptodon" and "Chlamydotherium" paleobiogeographic implications. Neues Jahrbuch für Geologie und Palaontologie, 258:353-363. doi: 10.1127/0077-7749/2010/0116

Osborn, H.F. 1903. Glyptotherium texanum, a new glyptodont from the lower Pleistocene of Texas. Bulletin of the American Museum of Natural History, 19:491-494.

Paula Couto, C. 1957. Sobre um gliptodonte do Brasil. Boletim Divisão de Geologia e Mineralogia, 165:137.

Paula Couto, C. 1983. Fossil mammals from the Cenozoic of Acre, Brazil. VI-Edentata Cingulata. Iheringia, Série Geologia, 8:33-4.

Pérez-Crespo, V.A.; Arroyo-Cabrales, J.; Alva-Valdivia, L.M.; Morales-Puente, P. \& Cienfuegos-Alvarado, E. 2012. Diet and habitat definitions for Mexican glyptodonts from Cedral (San Luis Potosí, México) based on stable isotope analysis. Geological Magazine, 149:153-157. doi:10.1017/S0016756811000951

Pérez, L.M.; Scillato-Yané, G.J. \& Vizcaíno, S.F. 2000. Estudio morfofuncional del aparato hioideo de Glyptodon cf. G. clavipes (Cingulata, Glyptodontidae). Ameghiniana, 37:293-299.
Pomi, L.H. 2008. Tafonomía y paleoecología de los Glyptodontidae (Mammalia) pleistocénicos de la provincia de Buenos Aires, Argentina. In: CONGRESO LATINOAMERICANO DE PALEONTOLOGÍA DE VERTEBRADOS, 3, 2008. Resúmenes, Neuquén, p. 200.

Porpino, K.O. \& Bergqvist, L.P. 2002. Novos achados de Panochthus (Mammalia, Cingulata, Glyptodontoidea) no Nordeste do Brasil. Revista Brasileira de Paleontologia, 4:51-62.

Porpino, K.O.; dos Santos F.C.M. \& Bergqvist, L.P. 2004. Registros de Mamíferos fósseis no Lajedo de Soledade, Apodi, Rio Grande do Norte, Brasil. Revista Brasileira de Paleontologia, 7:349-358.

Porpino, K.O.; Fernícola, J.C. \& Bergqvist, L.P. 2010. Revisiting the intertropical Brazilian species Hoplophorus euphractus (Cingulata, Glyptodontoidea) and the phylogenetic affinities of Hoplophorus. Journal of Vertebrate Paleontology, 30:911-927. doi:org/10.1080/02724631003765735

Pujos, F. 2008. Paleogeographic distribution and anatomical adaptations in Peruvian megatheriine ground sloths (Xenarthra: Megatherioidea). In: S.F. Vizcaíno \& W.J. Loughry (eds.) The Biology of the Xenarthra, Florida, University Press, p. 56-63.

Pujos, F. \& Salas, R. 2004. A systematic reassessment and paleogeographic review of fossil Xenarthra from Peru. Bulletin de l'Institut Français d'Etudes Andines, 33:331-377.

Ribeiro, A.M. \& Scherer, C.D. 2009. Mamíferos do Pleistoceno do Rio Grande do Sul, Brasil: estado atual do conhecimento. Quaternário do RS: Integrando Conhecimentos, p. 156-171 (Monografias da Sociedade Brasileira de Paleontologia).

Rincón,A.D. \& White, R.S. 2007. Los Xenarthra Cingulata del Pleistoceno tardío (Lujanense) de Cerro Misión, Estado Falcón, Venezuela. Boletín de la Sociedad Venezolana de Espeleología, 41: 2-12.

Rincón, A.D.; White, R.S. \& McDonald, H.G. 2008. Late Pleistocene cingulates (Mammalia: Xenarthra) from Mene de Inciarte Tar Pits, Sierra de Perijá, Western Venezuela. Journal of Vertebrate Paleontology, 28:197-207. doi:10.1671/02724634(2008)28[197:LPCMXF]2.0.CO;2

Rinderknecht, A. 1999. Estudios sobre la familia Glyptodontidae Gray, 1869. I. Nuevos registros para el Uruguay y consideraciones sistemáticas (Mammalia: Cingulata). Comunicaciones Paleontológicas del Museo de Historia Natural de Montevideo, 2:145-156.

Rodríguez, M.A.; Olalla-Tárraga, M.A. \& Hawkins, B.A. 2008. Bergmann's Rule and the geography of mammal body size in the Western Hemisphere. Global Ecology and Biogeography, 17:274-283. doi:10.1111/j.1466-8238.2007.00363.x

Simpson. G.G. 1929. The extinct land mammals of Florida. Annual Report of the Florida State Geological Survey, 20:229-279.

Soilbelzon, E. 2008. Los mamíferos del Ensenadense (Pleistoceno Inferior-Medio) del Este de la Región Pampeana, con énfasis en los Xenarthra. Bioestratigrafia, diversidad y correlaciones biogeográficas. Universidad Nacional de La Plata, PhD. thesis, 304 p.

Soibelzon, E.; Miño-Boilini, A.R.; Zurita, A.E. \& Krmpotic, C.M. 2010. Los Xenarthra del Ensenadense (Pleistoceno Inferior a Medio) de la Región Pampeana (Argentina). Revista Mexicana de Ciencias Geológicas, 27:449-469.

Soibelzon, E.; Zurita, A.E. \& Carlini, A.A. 2006. Glyptodon munizi Ameghino (Mammalia, Cingulata, Glyptodontidae): redescripción y anatomía. Ameghiniana, 43:377-384.

Takay, M.; Takemura, K.; Takemura, A.; Villarroel, C.; Hayashida, A.; Danhara, T.; Onho, T.; Franco, R.; Setoguchi, T \& Nogami, Y. 1992. Geology of La Venta, Colombia, South America. Kyoto University Primate Research Institute, Reports of the New World Monkeys, 8:1-17. 
Tauber, A.A. \& Di Ronco, J. 2000. Nuevo hallazgo de placas ventrales de Glyptodon Owen, 1839 (Mammalia, Cingulata, Glyptodontidae) en la Provincia de Córdoba, República Argentina. Boletín de la Academia Nacional de Ciencias (Córdoba), 64: 335-347.

Tauber, A. A. \& Palacios, M. E. 2007. Nuevo registro de mamíferos cuaternarios de gran porte en la Provincia de Santa Cruz, República Argentina. In: JORNADAS ARGENTINAS DE PALEONTOLOGÍA DE VERTEBRADOS, 23, 2007. Resúmenes, Trelew, p. 122.

Ubilla, M.; Perea, D.; Aguilar, C.G. \& Lorenzo, N. 2004. Late Pleistocene vertebrate from northern Uruguay: tools for biostratigraphic, climatic and environmental reconstruction. Quaternary International, 114:129-142. doi:10.1016/S1040-6182(03)00048-X

Vizcaíno, S.F.; Cassini, G.H.; Fernícola, J.C. \& Bargo, S. 2011. Evaluating habitats and feeding habits through ecomorphological features in glyptodonts (Mammalia, Xenarthra). Ameghiniana, 48:305-319.

Webb, S.D. 1978. A history of savanna vertebrates in the New World. Part II: South America and the Great Interchange. Annual Review Ecology Systematic, 9: 393-426.

Webb, S.D. 1985. Late Cenozoic mammal dispersal between the Americas. In: F.G. Stehli \& S.D. Webb (eds.) The Great American Biotic Interchange, Plenum Press, 357-386.

Zamorano, M.; Mones, A. \& Scillato-Yané, G.J. 2012. Redescripción y designación de un neotipo de Panochthus tuberculatus (Owen) (Mammalia, Cingulata, Glyptodontidae). Revista Brasileira de Paleontología, 15:113-122. doi:10.4072/rbp.2012.1.10
Zurita, A.E.; Carlini, A.A. \& Gillette, D. 2008. GlyptotheriumGlyptodon (Xenarthra, Glyptodontidae, Glyptodontinae): anatomy and paleobiogeography. Journal of Vertebrate Paleontology, 28:165A.

Zurita, A.E.; Carlini, A.A.; Gillette, D. \& Sánchez, R. 2011 a. Late Pliocene Glyptodontinae (Xenarthra, Cingulata, Glyptodontidae) of South and North America: morphology and paleobiogeographical implications in the GABI. Journal of South American Earth Sciences, 31:178-185. doi:10.1016/j. jsames.2011.02.001

Zurita, A.E.; Miño-Boilini, A.R.; Soibelzon E.; Carlini A.A. \& Paredes-Ríos, F. 2009. The diversity of Glyptodontidae (Xenarthra, Cingulata) in the Tarija Valley (Bolivia): systematic, biostratigraphic and paleobiogeographic aspects of a particular assemblage. Neues Jahrbuch für Geologie und Palaontologie, 251/2:225-237. doi:10.1127/0077-7749/2009/0251-0225

Zurita, A.E.; Oliveira, E.; Toriño, P.; Roriguez-Bualó, S.M.; ScillatoYané, G.J.; Luna, C. \& Krapovickas, J. 2011b. On the taxonomic status of some Glyptodontidae (Mammalia, Xenarthra, Cingulata) from the Pleistocene of South America. Annales de Paleontologie, 97:63-83. doi:10.1016/j.jsames.2011.02.001

Zurita,A.E.; Scarano, A.; Carlini, A.A.; Scillato-Yané, G.J. \& Soibelzon, E. 2011c. Neosclerocalyptus spp. (Cingulata: Glyptodontidae: Hoplophorini): cranial morphology and palaeoenvironments along the changing. Quaternary Journal of Natural History, 45:893-914. doi:10.1080/00222933.2010.536917

Received in January, 2012; accepted in August, 2012. 